\title{
HUBUNGAN MUTU PELAYANAN ASUHAN KEPERAWATAN DENGAN KEPUASAN PASIEN PENGGUNA BPJS KESEHATAN DI RUANG RAWAT INAP KELAS III RSUD MANGUSADA
}

\author{
THE RELATION OF THE NURSING CARE QUALITY SERVICE WITH \\ “BPJS” HEALTH INSURANCE MEMBER SATISFACTION ON THIRD \\ CLASS WARD IN RSUD MANGUSADA
}

\author{
Putu Widiastuti, IGAA Sherlyna Prihandhani, Ni Putu Rini Pradnyasari \\ STIKES Bina Usada Bali \\ Korespondens: sherlynaprihandhani@gmail.com
}

\begin{abstract}
High quality health service can be seen on five dimensions of responsiveness, reliability, assurance, empathy and tangible. According to interview and document analysis result at RSUD Mangusada, reducing the hospitalize patient happen from 64.804 in 2018 to 7.037 patients in 2016. This study aimed at finding the relation nursing care quality service with BPJS Health Insurance member satisfy on third in RSUD Mangusada. The study design was cross sectional with number of sample about 85 people chosen by purposive sampling technique with inclusion and exclusion criteria. The questionnaire used as instrument in this study then analyzed by univariate and bivariate tests. The test used chi-square ( $p$ value $<\alpha$, $\alpha=0$, 05). The statistic test result obtained that $p$ value $0,000<\alpha=0,05$, concluded that the quality service of five dimensions had significant relation with the BPJS health insurance member satisfaction. Based on the study done, suggested that the future health service maintaining the quality of nursing care quality service based on five dimensions quality services so the purpose of institution in patient satisfaction achieved.
\end{abstract}

Keywords: Quality Service, Dimension, Nursing Care, Nursing, Hospital

\begin{abstract}
ABSTRAK
Pelayanan kesehatan yang bermutu dapat dilihat berdasarkan lima dimensi mutu, yaitu cepat tanggap (responsiveness), kehandalan (reliability), terjamin (assurance), empati (empathy), dan bukti langsung (tangible). Berdasarkan hasil wawancara dan analisis dokumen di RSUD Mangusada terjadi penurunan jumlah pasien rawat inap dari 64.804 pada tahun 2015 menjadi 7.307 jiwa pada tahun 2018. Penelitian ini bertujuan untuk mengetahui hubungan mutu pelayanan asuhan keperawatan dengan kepuasan pasien pengguna BPJS Kesehatan di ruang rawat inap kelas III Rumah Sakit Umum Daerah Mangusada. Desain penelitian ini adalah Cross Sectional dengan jumlah sampel 85 orang yang dipilih melalui teknik purposive sampling dengan menggunakan kriteria inklusi dan ekslusi. Kuesioner digunakan sebagai instrumen dalam penelitian ini kemudian dianalisis dengan menggunakan uji univariat dan bivariat. Uji yang digunakan pada penelitian ini Chi-square ( $\mathrm{p}$ value $<\alpha, \alpha=0,05$ ). Hasil uji statistik diperoleh hasil bahwa $p$ value $0,000<\alpha=0,05$, sehingga dapat disimpulkan bahwa mutu pelayanan yang terdiri dari lima dimensi mutu mempunyai hubungan yang signifikan dengan kepuasan pasien pengguna BPJS Kesehatan. Berdasarkan hasil penelitian, disarankan agar kedepannya pihak pelayanan kesehatan mempertahankan mutu pelayanan asuhan
\end{abstract}


keperawatan berdasarkan lima dimensi mutu pelayanan sehingga tujuan dari institusi dalam hal kepuasan pasien mampu tercapai.

\section{Kata Kunci: Mutu Pelayanan, Dimensi, Asuhan Keperawatan, Perawat, Rumah Sakit}

\section{PENDAHULUA}

Pelayanan keperawatan memiliki peranan yang penting dalam pelaksanaan pelayanan kesehatan di berbagai tatanan salah satunya adalah rumah sakit. Rumah sakit merupakan penyelenggara pelayanan kesehatan yang memerlukan tenaga keperawatan lebih banyak bila dibandingkan dengan tenaga kesehatan lainnya. Hal tersebut dikarenakan diperlukannya tenaga keperawatan dalam menunjang pelaksanaan pelayanan kesehatan melalui pelayanan asuhan keperawatan (Asmuji, 2013).

Pelayanan asuhan keperawatan didasarkan pada kaidah profesi keperawatan melalui pendekatan holistik yang mencakup aspek biologis, psikologis, sosial, kultural dan spiritual. Tenaga perawat profesional diharapkan memberikan kualitas pelayanan yang baik. Hal tersebut dikarenakan keberadaan perawat yang bertugas selama 24 jam dalam memberikan pelayanan asuhan keperawatan kepada pasien, sehingga perawat dituntut untuk mampu memberikan pelayanan kesehatan yang bermutu (Nursalam, 2011).

Mutu adalah kesempurnaan dari produk jasa dengan mematuhi standar yang telah ditetapkan, mutu pelayanan yang biasa digunakan dalam penilaian suatu kualitas pelayanan kesehatan mengacu pada lima dimensi mutu, yaitu cepat tanggap (responsiveness), kehandalan (reliability), terjamin (assurance), empati (empathy), dan bukti fisik (tangible), kelima dimensi mutu pelayanan dapat digunakan untuk mewujudkan kepuasan (Muninjaya, 2011).

Kepuasan pasien merupakan salah satu ukuran keberhasilan pelayanan yang diberikan rumah sakit (Rasheed, 2012). Kepuasan pasien juga merupakan ukuran yang penting tentang efektivitas pemberi pelayanan kesehatan dalam memenuhi kebutuhan dan harapan pasien. Pasien dikatakan puas jika pelayanan yang diterima sesuai dengan harapan atau melampaui harapan yang dinginkan. Begitu sebaliknya, jika pelayanan yang diterima oleh pasien tidak sesuai harapan maka pasien cenderung merasa tidak puas (Kotler, 2017).

Salah satu isu yang berkembang yang dikutip dari koran lokal tahun 2014 yaitu adanya keluhan dari masyarakat bahwa kurang efektifnya pelayanan keperawatan kepada pasien dengan kartu pengguna Badan Penyelenggara Jaminan 
Sosial (BPJS) di rumah sakit (Putra, 2015).

Hal itu terjadi karena dinamika tuntutan pasien yang demikian cepat berubah namun tidak diimbangi dengan kecepatan perubahan pola kerja dan tindakan perawat.

Penelitian sebelumnya yang dilakukan oleh Sulistyo (2016) tentang Hubungan Kualitas Pelayanan Kesehatan dengan Tingkat Kepuasan Pasien BPJS di Puskesmas Delanggu Kabupaten Klaten menyatakan bahwa ada hubungan yang signifikan antara kualitas asuhan pelayanan kesehatan dengan tingkat kepuasan pasien BPJS.

Studi pendahuluan dilakukan pada tanggal 22 Oktober 2016 di ruang rawat inap kelas III RSUD Mangusada dengan 10 pasien dan keluarga pasien. Hasil studi pendahuluan menyatakan bahwa sebanyak enam (60\%) dari 10 pasien menyatakan perawat tidak segera datang apabila pasien membutuhkan, selain itu lima (50\%) dari 10 pasien menyatakan perawat kurang teratur dalam menjenguk atau melihat kondisi serta perhatian terhadap pasien, dan lima (50\%) dari 10 pasien menyatakan perawat juga kurang konsisten dalam memberikan pelayanan kesehatan terhadap pasien.

Selain hasil wawancara tentang kepuasan pasien, data jumlah pasien rawat inap juga menggambarkan-pada bulan Januari sampai September 2015 jumlah pasien yang menggunakan kartu BPJS di keseluruhan ruang rawat inap di RSUD Mangusada adalah 61.483 jiwa. Pada tahun 2016 pengguna BPJS mengalami penurunan dari bulan Januari sampai September 2016 menjadi 7.307 jiwa (RSUD Mangusada, 2018).

Berdasarkan latar belakang tersebut Dengan adanya bukti fisik bahwa pelayanan keperawatan diperlukannya tenaga keperawatan dalam menunjang pelaksanaan pelayanan kesehatan melalui pelayanan asuhan keperawatan. Kehandalan yang dapat dilakukan ketika melakukan pelayanan asuhan keperawatan yaitu berdasarkan pada kaidah profesi keperawatan melalui pendekatan holistik yang mencakup aspek biologis, psikologis, sosial, kultural dan spiritual. Daya tanggap yang dimiliki berupa keberadaan perawat yang bertugas selama 24 jam dalam memberikan pelayanan asuhan keperawatan kepada pasien, sehingga perawat dituntut untuk mampu memberikan pelayanan kesehatan yang bermutu. Empati yang muncul akibat adanya keluhan dari masyarakat bahwa kurang efektifnya pelayanan keperawatan kepada pasien dengan kartu pengguna Badan Penyelenggara Jaminan Sosial (BPJS) di rumah sakit (Putra, 2015). Sehingga menimbulkan dua kemungkinan yaitu, 
mampu meningkatkan kepuasan pasien dengan pelayanan yang diterima yang sudah sesuai dengan harapan atau melampaui harapan yang dinginkan. Begitu sebaliknya, jika pelayanan yang diterima oleh pasien tidak sesuai harapan maka pasien cenderung merasa tidak puas.

\section{METODE}

Mutu pelayanan dilakukan dengan menggunakan jasa. Pelayanan yang bermutu yaitu pelayanan yang diberikan sesuai dengan prosedur dan standar pada kode etik profesi yang telah ditetapkan. Bukti fisik (Tangibles) yang meliputi penampilan fasilitas fisik seperti penampilan petugas. Kehandalan (Reliability) yaitu kemampuan memberikan pelayanan sesuai dengan yang dijanjikan. Daya tanggap (Responsiveness) yaitu kesediaan untuk membantu pelanggan, respon dan memberikan pelayanan yang cepat. Jaminan (Assurance) yaitu kegiatan untuk menjamin kepastian terhadap pelayanan yang akan diberikan kepada pelanggan. Empati (Emphaty) yaitu membina hubungan dan perhatian secara individual.

Menurut Kotler (2007), kepuasan adalah perasaan senang atau kecewa seseorang yang muncul setelah membandingkan antara kesan terhadap kinerja atau hasil produk dan harapan- harapannya. Pasien dikatakan puas jika pelayanan yang diterima sesuai dengan harapan atau melampaui harapan yang diinginkan. Begitu sebaliknya, jika pelayanan yang diterima oleh pasien tidak sesuai harapan maka pasien akan merasa tidak puas (Kotler, 2007). Cara pengukuran dalam penelitian ini menggunakan kuesioner dengan hasil ukur pasien dikatakan puas bila skor $\geq 38$ sedangkan pasien dikatakan tidak puas bila skor $<38$. Penelitian ini menggunakan metode penelitian kuantitatif dengan desain penelitian korelasional dan dengan desain penelitian- Cross Sectional.

Populasi dalam penelitian ini adalah pasien BPJS Kesehatan di seluruh ruang rawat inap kelas III Rumah Sakit Umum Daerah Mangusada pada bulan Januari hingga September 2016 sebanyak 5.103 orang dengan rata-rata 567 orang per bulan. Sampel dalam penelitian ini diambil dengan menggunakan teknik sampling jenis non probability sampling yaitu purposive sampling dimana variabel independen dan dependen dinilai secara simultan pada suatu saat, jadi tidak ada tindak lanjut. Artinya tidak semua subjek penelitian harus diobservasi pada hari atau waktu yang sama, akan tetapi variabel independen maupun variabel dependen dinilai hanya satu kali saja menggunakan teknik 
pemilihan sampel dengan melihat kriteria inklusi yaitu pasien berumur 16-60 tahun, mengerti pertanyaan yang diajukan pada lembar kuesioner (bisa baca dan tulis berbahasa Indonesia), pasien yang dirawat inap minimal tiga hari, pasien Pengguna BPJS Kesehatan, dan pasien dalam keadaan sadar serta kriteria eksklusi. Sampel dalam penelitian ini adalah 85 responden.

Instrumen (alat ukur) yang digunakan dalam penelitian ini adalah kuesioner. Kuesioner yang pertama adalah mutu pelayanan asuhan keperawatan yang terdiri dari 19 pernyataan. Kuesioner yang kedua adalah kepuasan pasien. Kuesioner ini merupakan kuesioner kepuasan pasen yang akan dipersepsikan oleh pasien BPJS di ruang rawat inap. keadaan pasien. Peneliti melakukan uji hipotesis menggunakan uji korelasi. Nilai p pada uji Chi-square dibandingkan dengan nilai $\alpha$, dengan $\alpha=0,05$.

\section{HASIL DAN PEMBAHASAN}

Rumah Sakit Umum Daerah Mangusada adalah rumah sakit negeri yang dalam perkembangannya mampu meraih akreditasi tipe B. Rumah sakit ini juga menampung pelayanan rujukan dari rumah sakit kabupaten. Ruang rawat inap di RSUD Mangusada ini terbagi menjadi 7 ruangan, diantaranya : ruang Cilinaya, Kecak, Janger, Oleg, Margapati, Paviliun dan Intensif. Dari 7 ruangan tersebut terdapat jumlah keseluruhan tempat tidur di ruang rawat inap adalah 203 tempat tidur, dimana 118 diantaranya merupakan tempat tidur seluruh kelas III. Dengan banyaknya ruangan yang disediakan tentu saja tenaga kesehatan yang diperlukan banyak. Adapun jumlah umum dari tenaga kesehatan di ruang rawat inap BRSU Mangusada diantaranya : perawat 146 orang, dokter 98 orang, bidan 34 orang dan administrasi 9 orang.

Tabel 1. Distribusi Persepsi Mutu Pelayanan Asuhan Keperawatan dan Kepuasan Pasien di Ruang Rawat Inap Kelas III Pengguna BPJS Kesehatan

\begin{tabular}{lcc}
\hline Kategori & $\begin{array}{c}\text { Frekue } \\
\text { nsi (f) }\end{array}$ & $\begin{array}{c}\text { Persentase } \\
(\%)\end{array}$ \\
\hline Bukti Fisik & & \\
Kurang Baik & 11 & 12,9 \\
Baik & 74 & 87,1 \\
Kehandalan & & \\
Kurang & 9 & 10,6 \\
BaikBaik & 76 & 89,4 \\
Daya & & \\
Tanggap & & \\
Kurang & 7 & 8,2 \\
BaikBaik & 78 & 91,8 \\
Jaminan & & \\
Kurang & 4 & 4,7 \\
BaikBaik & 82 & 95,3 \\
Empati & & \\
Kurang Baik & 4 & 4,7 \\
Baik & 82 & 95,3 \\
Kepuasan & & \\
Puas & 75 & 88,2 \\
Kurang Puas & 10 & 11,8 \\
& & \\
\hline
\end{tabular}

Tabel 1 menunjukkan bahwa kebanyakan responden (74 orang) memiliki persepsi bukti fisik baik, persepsi kehandalan baik 
$(89,4 \%)$, persepsi daya tanggap baik $(91,8 \%)$, persepsi jaminan baik $(95,3 \%)$, persepsi empati baik (95,3\%). Untuk kepuasan pasin $88,2 \%$ responden mengatakan puas.

Tabel 2. Kepuasan Pasien Berdasarkan Mutu Pelayanan Asuhan Keperawatan

\begin{tabular}{cccc}
\hline Variabel & \multicolumn{2}{c}{ Kepuasan Pasien } & \\
\cline { 2 - 3 } Bebas & $\begin{array}{c}\text { Kurang } \\
\text { Puas }\end{array}$ & Puas & \multirow{2}{*}{$\mathbf{p}^{*}$} \\
\cline { 2 - 3 } & $\mathbf{n}(\%)$ & $\mathbf{n}(\%)$ & \\
\hline Bukti Fisik & & & \\
Kurang & $10(11,8)$ & $1(1,2)$ & \\
Baik & $0(0,0)$ & $74(87,1)$ & $<0,001$ \\
Baik & & & \\
Kehandalan & $8(9,4)$ & $1(1,2)$ & \\
Kurang & $2(2,4)$ & $74(87,1)$ & $<0,001$ \\
Baik & & & \\
Baik & $6(7,1)$ & $1(1,2)$ & \\
Daya & $4(4,7)$ & $74(87,1)$ & $<0,001$ \\
Tanggap & & & \\
Kurang & $4(4,7)$ & $0(1,0)$ & \\
Baik & $6(7,1)$ & $75(88,2)$ & $<0,001$ \\
Baik & $3(3,5)$ & $1(1,2)$ & \\
Jaminan & $7(8,2)$ & $74(87,1)$ & $<0,001$ \\
Kurang & & & \\
Baik & & & \\
Baik & & & \\
Empati & & & \\
Kurang & & & \\
Baik & & & \\
Baik & & & \\
& & & \\
\hline
\end{tabular}

Hasil analisis bivariat dengan chi square menunjukkan bahwa bukti fisik diperoleh nilai $p$ value sebesar 0,000 dengan nilai $\alpha=0,05$, maka Ha diterima ada hubungan yang signifikan antara dimensi mutu bukti fisik asuhan keperawatan dengan kepuasan pasien pengguna BPJS Kesehatan, kehandalan diperoleh nilai $p$ value sebesar 0,000 dengan nilai $\alpha=0,05$, maka $\mathrm{Ha}$ diterima ada hubungan yang signifikan antara dimensi mutu kehandalan asuhan keperawatan dengan kepuasan pasien pengguna BPJS Kesehatan, daya tanggap diperoleh nilai $p$ value sebesar 0,000 dengan nilai $\alpha=0,05$, maka dapat disimpulkan bahwa $\mathrm{Ha}$ diterima ada hubungan yang signifikan antara dimensi mutu daya tanggap asuhan keperawatan dengan kepuasan pasien pengguna BPJS Kesehatan, jaminan diperoleh nilai $p$ value sebesar 0,000 dengan nilai $\alpha=0,05$, maka dapat disimpulkan bahwa Ha diterima ada hubungan yang signifikan antara dimensi mutu jaminan asuhan keperawatan dengan kepuasan pasien pengguna BPJS Kesehatan dan empati diperoleh nilai $p$ value sebesar 0,000 dengan nilai $\alpha=0,05$, maka dapat disimpulkan bahwa $\mathrm{Ha}$ diterima ada hubungan yang signifikan antara dimensi mutu empati asuhan keperawatan dengan kepuasan pasien pengguna BPJS Kesehatan. Responden dengan persepsi baik terhadap mutu pelayanan asuhan keperawatan cenderung memiliki kepuasan yang baik.

Variabel bukti fisik meliputi penataan ruang rawat inap yang rapi dan bersih, kenyamanan ruang rawat inap, kelengkapan alat-alat medis serta tempat tidur telah disiapkan dalam keadaan rapi, bersih dan siap dipakai. Berdasarkan 
indikator tersebut masih ada yang dirasakan kurang baik oleh 12, 9\% responden, yaitu ruang rawat inap yang belum tertata rapi dan bersih. Kehandalan meliputi prosedur penerimaan pasien dilayani secara cepat dan tepat tidak berbeli-belit. Berdasarkan indikator tersebut masih ada yang dirasakan kurang baik oleh $10,6 \%$ responden, yaitu prosedur penerimaan pasien belum dilayani secara cepat dan tepat serta berbeli-belit. Daya tanggap meliputi perawat bersikap ramah dan sopan serta perawat memperhatikan kebutuhan dan keluhan pasien. Berdasarkan indikator tersebut masih ada yang dirasakan kurang baik oleh $8,2 \%$ responden, yaitu pada indikator perawat belum bersikap ramah dan sopan. Jaminan meliputi perawat terdidik dan mampu melayani pasien. Berdasarkan hasil penelitian ini masih ada pelayanan asuhan keperawatan yang dirasakan kurang baik oleh $4,7 \%$ responden yaitu perawat terdidik dan belum mampu melayani pasien. Terakhir yaitu empati meliputi perawat meluangkan waktu khusus untuk berkomunikasi dengan pasien. Berdasarkan hasil penelitian ini masih ada pelayanan asuhan keperawatan yang dirasakan kurang baik oleh $4,7 \%$ responden yaitu perawat tidak meluangkan waktu khusus untuk berkomunikasi dengan pasien. Berdasarkan analisis bivariat menunjukkan ada hubungan bermakna dengan kepuasan pasien. Dimensi bukti fisik merupakan segala hal yang langsung dapat dirasakan klien melalui indra penglihatannnya seperti penataan ruang rawat inap yang rapi dan bersih, kenyamanan ruang rawat inap, kelengkapan alat-alat medis serta tempat tidur telah disiapkan dalam keadaan rapi, bersih dan siap dipakai dalam pelayanan keperawatan. Hasil penelitian ini sejalan dengan penelitian yang dilakukan oleh Aliman (2013) yang berjudul Perceptions of Service Quality and Behavioral Intentions a Mediation Effect of Patient Satisfaction in the Private Health Care in Malaysia, bahwa sebagian besar menyatakan dimensi bukti fisik baik, yaitu sebesar 62 (55, 9\%). Dimensi kehandalan merupakan kemampuan untuk memberikan pelayanan yang tepat dan tepercaya yaitu dengan kesiapan perawat melayani pasien setiap saat, perawat melaporkan secara detail perubahan pasien kepada dokter pada saat berkunjung, perawat selalu memberi obat pasien sesuai prosedur pemberian obat. Pelayanan yang tepercaya adalah pelayanan yang konsisten dan kompeten (Asmuji, 2013). Hasil penelitian ini sejalan dengan penelitian yang dilakukan oleh Ester Nunuk (2009) yang berjudul Analisis Pengaruh Persepsi Mutu Pelayanan Asuhan Keperawatan terhadap Kepuasan Klien 
Rawat Inap di RSU Puri Asih bahwa sebagian besar menyatakan dimensi kehandalan baik $58(52,3 \%)$.

Berdasarkan teori, ketanggapan merupakan kemampuan untuk membantu dan merespon permintaan konsumen dengan cepat dan penuh keramahan serta kesopanan (Tjiptono, 2016). Hasil tersebut sejalan dengan penelitian dari Rasheed (2012) yang berjudul Client Satisfaction and Perceptions About Quality of Health Care at a Primary Health Centre of Delhi India, bahwa sebagian besar menyatakan dimensi daya tanggap baik $64(57,7 \%)$.

Chunlaka (2010) berpendapat bahwa dimensi jaminan pada asuhan keperawatan seperti menjaga kerahasiaan pasien selama berada diruang rawat inap, dan meningkatkan kepercayaan pasien serta membantu dalam proses kesembuhan pasien. Hasil penelitian ini sejalan dengan penelitian Mastiur (2012) yang berjudul Pengaruh Mutu Pelayanan Asuhan Keperawatan terhadap Kepuasan Pasien Rawat Inap di RSUD Doloksanggul, bahwa sebagian besar menyatakan dimensi jaminan baik $59(53,2 \%)$.

Hasil analisa responden sebagian besar menyatakan dimensi empati baik sebesar 95,3\%. Hasil tersebut sejalan dengan penelitian yang dilakukan oleh Manimaran (2010) bahwa sebagian besar menyatakan dimensi empati baik 57 $(51,4 \%)$. Dimensi empati (empathy) yaitu perawat selalu mengingatkan keamanan akan menyimpan barang berharga pasien dan keluarganya, waktu untuk berkonsultasi keluarga pasien terpenuhi, dan menghibur dan memberikan dorongan kepada pasien supaya cepat sembuh.

Hasil analisa responden sebagian besar menyatakan puas sebesar 75 responden (88,2\%). Kotler (2017) mengatakan bahwa kepuasan pasien adalah tingkat perasaan seseorang setelah membandingkan kinerja atau hasil yang dia rasakan dibandingkan dengan harapannya. Sri (2016) mempunyai pendapat yang hampir serupa yang menyatakan kepuasan pelanggan merupakan bentuk evaluasi dari pelanggan terhadap produk yang telah mereka dapatkan, sudah sesuai dengan yang diharapkan bahkan dapat melebihi harapan mereka. Bentuk dari evaluasi kepuasan pelanggan terhadap produk jasa maka akan dapat mempengaruhi pelanggan untuk datang kembali dan mampu mempengaruhi konsumen lainnya.

Hal ini sesuai dengan penelitian Hermanto (2016) yang berpendapat bahwa kepuasan pasien dinilai berdasarkan interprestasi responden tentang kesesuaian antara harapan dengan kenyataan meliputi kecepatan petugas dalam memberikan 
pertolongan, ketersediaan sarana dan prasarana yang dibutuhkan pasien dan keramahan petugas dalam memberikan pelayanan. Berdasarkan hasil penelitian ini dapat disimpulkan bahwa, kepuasan maupun ketidak puasan pasien sangat berhubungan dengan pelayanan yang diberikan kepada pasien karena pasien dapat merasakan secara langsung pelayanan daya tanggap yang perawat berikan dari awal pelayanan yang diterima pasien sampai akhir pelayanan di ruang rawat inap.

Bukti fisik, kehandalan, daya tanggap, jaminan dan empati merupakan faktor yang sangat penting dalam kualitas asuhan keperawatan, sehingga nantinya perawat mampu memberikan pelayanan yang bermutu dan memuaskan pasien serta dapat menumbuhkan rasa percaya pasien untuk mendapatkan pelayanan asuhan keperawatan kembali di rumah sakit tersebut (Chen \& Chang, 2017).

\section{SIMPULAN}

Sebagian besar pasien rawat inap kelas III pengguna BPJS Kesehatan merasa puas terhadap pelayanan asuhan keperawatan dengan pasien BPJS Kesehatan di ruang rawat inap kelas III RSUD Mangusada, pengguna BPJS Kesehatan dengan pelayanan asuhan keperawatan di ruang rawat inap kelas III RSUD Mangusada dan mampu menganalisis hubungan mutu pelayanan asuhan keperawatan dengan kepuasan pasien pengguna BPJS Kesehatan di ruang rawat inap kelas III RSUD Mangusada. Hasil uji statistik menunjukkan terdapat hubungan dimensi bukti fisik, kehandalan, daya tanggap, jaminan dan empati terhadap kepuasan pasien rawat inap kelas III pengguna BPJS Kesehatan.

\section{UCAPAN TERIMA KASIH}

Kami ucapkan terima kasih kepada STIKES Bina Usada Bali dalam membantu pembiayaan penelitian ini.

\section{DAFTAR PUSTAKA}

Asmuji. (2013). Manajemen keperawatan Cetakan Ke II. Yogyakarta: Ar Ruzz Media.

Chen, W., \& Chang, L. (2017). Research into Care Quality Criteria for Long Term CaChen, W., \& Chang, L. (2017). Research into Care Quality Criteria for Long Term Care Institutions. Retrieved from http://journals.lww.com/jnrtwna/Abst ract/2007.re Institutions. Retrieved from

http://journals.lww.com/jnrtwna/Abst $\mathrm{ract} / 2007$.

Chunlaka, P. (2010). International Patients Satisfaction toward Nurses Service Quality at Samitivej Srinakarin Hospital. Retrieved from http://thesis.swu.ac.th/swuthesis/Bus_ Eng_Int_Com/Poramaphorn.C.pdf

Hermanto, D. (2016). Pengaruh Persepsi Mutu Pelayanan Kebidanan terhadap Kepuasan Pasien Rawat Inap Kebidanan di RSUD Dr. H. Soemarno Sosroatmodjo Bulungan Kalimantan Timur. Semarang: Universitas Diponogoro. 
Kotler, P. (2017). Dasar-dasar Pemasaran. Jilid Sembilan. Edisi Bahasa Indonesia. Jakarta: PT. Indeks.

Manimaran, S., D. (2010). A Study of Patients Expectation and Satisfaction in Dindigul Hospitals. Retrieved from http://ipublishing.co.in/ajmrvol1no1/ EIJMRS 1004.pdf.

Muninjaya, A. (2011). Manajemen Mutu Pelayanan Kesehatan. Jakarta: EGC.

Nursalam. (2011). Manajemen Keperawatan: Aplikasi dalam Praktik Keperawatan Profesional Edisi Ketiga. Jakarta: Salemba Medika.

Putra, S. (2015). Hubungan Pelayanan Asuhan Keperawatan dengan Kepuasan Pasien Pengguna Kartu BPJS di Ruang Rawat Inap Zal Bedah RSUD DR. Achmad Mochtar Bukit tinggi. Retrieved from file:///C:/Users/user/Downloads/Docu ments/47-96-1-PB.pdf

Rasheed, N., \& Dkk. (2012). Client Satisfaction and Perceptions About Quality of Health Care at a Primary Health Centre of Delhi, India. Retrieved from file://C:/Users/user/AppData/Local/T emp/236-1740-1-PB.pdf

RSUD Mangusada. (2018). Laporan Jumlah Pasien BPJS Kesehatan. Badung.

Sri. (2016). Analisis Pengaruh Persepsi Pasien tentang Mutu Pelayanan Dokter Spesialis Obstetri dan Ginekologi dengan Minat Kunjung Ulang Pasien di Instalasi Rawat Jalan RSI Sultan Agung Semarang. Universitas Diponogoro.

Sulistyo, P. (2016). Hubungan Kualitas Pelayanan Kesehatan dengan Tingkat Kepuasan Pasien BPJS di Puskesmas Delanggu Kabupaten Klaten. Retrieved from file:///C:/Users/user/Downloads/Docu ments/01-gdl-petrusbamb-1465-1skripsi-o.pdf

Tjiptono, F. (2016). Total Quality
Management. Edisi ke-5 (A. Offset, Ed.). Yogyakarta. 